\title{
DETERMINATION OF SOIL QUALITY AS A FOUNDATION OF SUSTAINABLE LAND MANAGEMENT FOR CHILLI IN THE AGROFORESTRY SYSTEM BASED ON COCONUTS IN SANDY SOIL OF BUGEL BEACH
}

\author{
Dina Ruslanjari \\ The Graduate School of Universitas Gadjah Mada \\ Email: dienarus@ugm.ac.id \\ Taufan Alam \\ Agriculture Faculty Universitas Gadjah Mada
}

\begin{abstract}
ABSTRAK
Kualitas tanah tidak dapat diukur secara langsung, dimana indikator harus diimbangi sifat fisik, kimia dan biologi, yang semuanya berperan secara keseluruhan terhadap karakter tanah. Tujuan dari penelitian ini adalah untuk mengetahui hubungan antara faktor kualitas tanah dan pengkajian pengaruh kualitas tanah terhadap hasil cabai. Eksplorasi dilakukan di Pantai Bugel, Kecamatan Panjatan, Kulonprogo, D. I. Yogyakarta. Penelitian ini menggunakan metode randomized complete block design (RCBD) single factor. Faktor yang diamati adalah zona agroforestry awal (intensitas naungan 0-30\%), intensitas tengah (intensitas naungan 31-60\%) dan intensitas akhir (naungan> 60\%) berdasarkan pada kelapa yang ada di lokasi tanah berpasir Pantai Bugel. Pengumpulan data berupa fisik, bentuk kimia, bentuk biologis dan produksi cabai. Analisis data adalah ANOVA dengan uji LSD 5\%, Structured Equitation Modeling (SEM), Analisis Faktor dan Regresi Linier. Hasil investigasi menunjukkan fase agroforestri awal memiliki produksi cabai tertinggi, yang setelah itu adalah fase agroforestri menengah dan fase akhir agroforestry. Hasil SEM menunjukkan karakteristik biologis tanah secara umum berpengaruh langsung terhadap produksi cabai dan interaksi antara karakteristik fisik dengan karakteristik kimia tanah. Dua set faktor ditemukan yaitu faktor I (BV, kelembaban tanah, permeabilitas, $\mathrm{pH} \mathrm{H2O,} \mathrm{C-Organik,} \mathrm{KPK,}$ N-total, P-total, ketersediaan P, K-total, K-dd, Ca-dd , mg-dd, Na-dd dan jumlah mikroba total) dan faktor II (total mikroba dan respirasi total). Faktor kualitas yang mempengaruhi produksi cabai adalah jumlah total mikroba.
\end{abstract}

Kata Kunci: Agroforestri; Cabai; Kelapa;Kualitas tanah; Pasir pantai.

\section{ABSTRACT}

The quality of soil cannot be measured directly, in which indicators need to be arbitrated of physical, chemical and biological properties, all of those affect the character of soil. The objective of this study was to identify the relationship between factors of soil quality and to review the effect of soil quality towards chili production. The exploration was done at Bugel Beach, Panjatan Sub-District, Kulonprogo, and DIY. Methods that were used in this study were Randomized Complete Block Design (RCBD) single factor. The factors was divided into initial agroforestry zone (shade intensity 0-30\%), middle (shade intensity 31-60\%) and final (shade intensity $>60 \%$ ) based on coconuts that was present at the location of sandy soil of Bugel Beach. Data collection was in physical, chemical, and biological form also in chili production. Data analyses were ANOVA with 5\% LSD test, Structural Equitation Modelling (SEM), Factor Analysis and Stepwise Regression. The result of this study showed that initial agroforestry phase had the highest chilli production which followed by middle agroforestry and final agroforestry phase. SEM result showed that biological characteristic of soil in general directly affect the chili production and 
an interaction was evidence between physical and chemical characteristics of the soil. Two sets of the factors were found in factor I (BV, soil moisture, permeability, $\mathrm{pH} \mathrm{H}_{2} \mathrm{O}$, C-Organic, KPK, N-total, P-total, P-availability, K-total, K-dd, Ca-dd, mgdd, Na-dd and total of microbes) and factor II (microbial and respiration total). Quality factor which effected chili production was the amount of total microbes.

Keywords: Agroforestry; Beach sand; Chili; Coconuts; Soil quality.

\section{INTRODUCTION}

Indonesia has coastal line which covers $106.000 \mathrm{~km}$ with potential of 1.060 .000 ha (Saparso. 2008) land area. This vast land area can replace the decrease of land that occurs in 41.2 years. Taking optimal advantage of sandy beach area can give positive impact toward the increase of land productivity and also control the environment (sand erosion) on coastal areas (Saparso, 2008). Beach area of south of D. I. Yogyakarta is one of the most specific model of development of horticultural crop plants on coastal land area (Kartonegoro, 2003). One example of land potential that has not been taken as advantage is sandy beach land under coconut tree. The development of potential horticultural plant under coconut trees has a huge chance thus the majority of horticultural plants is C3 plant type. Plants with such C3 type have the ability to grow well at certain shaded conditions until a certain point. One comodity of horticulture that has high economic value and worthy to be developed is the chili plant.

The problem that arises in the advancement of chili agroforestry with coconut at sandy area is lighting and quality factor that is considerably low. Soil quality cannot be determined directly, in which therefore soil quality indicatior is needed (Makalew, 2011). Soil quality indicator is soil characteristic that can be measured which consists of physical, chemical, and biology characteristic of the soil. Andrews et al., (2004) mentioned that precise assessment of soil quality is to measure the change of soil function as a reaction on management, within the context of what is expected from the soil, genuine characteristics and the impacts from the environment, including temperature and rainfall. Soil quality indicator is a chemical, physical, and biological characteristic of soil which is sensitive towards disturbance and potray the on going ecosystem in the soil.

One way to measure the soil quality is to determine factors of the soil quality which plays a part towards the outcome of chili with statistical data reduction. The quantitative research of soil quality expects that it can function as one foundation of maintaining land sustainability for chili argoforestry with coconut in sandy beach soil.

Administratively, this research was located at Bugel Village, Panjatan Sub-District, Kulonprogo, and D. I. Yogyakarta. The research started in April until August 2015. It was a field research with Complete Random Grouping Design (Rancangan Acak Kelompok Lengkap) using single factor. Objects that were investigated were initial agroforestry zone (shade intensity 0-30\%), middle (shade intensity 31$60 \%$ ) and final (shade intensity $>60 \%$ ), based on coconuts from Bugel Beach area.

Data collection included permeability, volume weight, moisture level available, C-

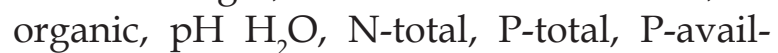
able, K-total, K-exchange, Na-exchange, Caexchange, Mg-exchange, exchange of cation capacity, sum of total microbe, respiration total, and fresh chili weight. First analysis was homogenity testing Bartlette 5\% to see data homogenity. If homogenity data was continued with diversity analysis (ANOVA) a 5\% and at least significant different (LSD) test a $5 \%$. The next step was the determination of soil factors that play a role in effecting chili using factor analysis (principal factor analysis), structural equation modelling (SEM) and gradual regression analysis (stepwise regression). The outcome from the research analysis was used to specify quality index of soil quality for chili plant management.

\section{DISCUSSION}

According to the result of the trials in planting chili at its own agroforestry phases 
based on coconut, showed that there were significant differences toward chili production (Picture 1). Initial agroforestry phase indicated the highest level of production, followed by middle agroforestry phase and then final phase. That was happen because of the lighting gradients and the level of soil fertility at each phase.

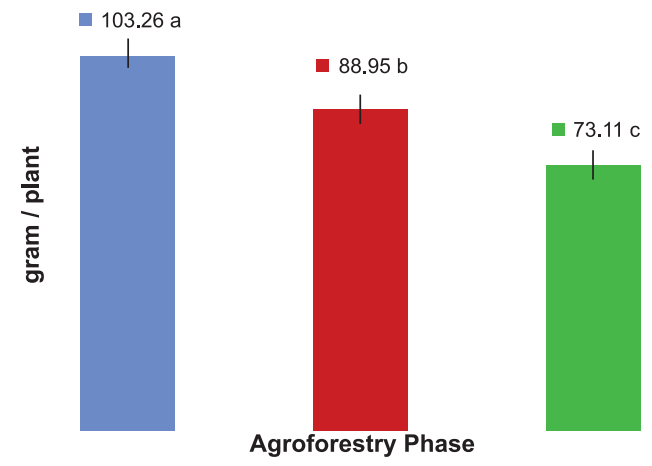

Picture 1. Chili profuction on different agroforestry phases
Low lighting intensity is a condition that limits the lighting received by the plant under the light itself either from its quality or quantity. Shading in general decreases the lighting intensity that can be received by the plant in which therefore disrupts growth and deducts the chili outcome. In this study, lighting factor would not be elaborated further because the focus of this study is to qualify the soil factors that effect the outcome of chili plants.

The first step was to see the factor of soil quality that impact the chili starting with screening by ANOVA a $5 \%$ on the variability of physical, chemical, and biological characteristics of the soil. The result of the screening showed that all parameters of the soil being investigated have a range on some agroforestry phases. The result of the screening was a guide for factor analysis. This result of factor analysis tried to explain the parameters that interact in each set of factors.

Table 1. Screening Result and Factor Analysis on Agroforestry Phase

\begin{tabular}{lllll}
\hline No. & \multicolumn{1}{c}{ Parameter } & \multicolumn{1}{c}{ Factor I } & Factor II & Commulanity \\
\hline 1 & Volume Weight & $\mathbf{0 , 9 1 0}$ & 0,356 & 0,956 \\
2 & Soil Moisture & $\mathbf{0 , 9 3 4}$ & 0,315 & 0,971 \\
3 & Permeability & $\mathbf{- 0 , 9 2 9}$ & $-0,315$ & 0,962 \\
4 & pH H2O & $\mathbf{0 , 9 2 4}$ & 0,061 & 0,857 \\
5 & C-organic & $\mathbf{0 , 9 6 2}$ & 0,253 & 0,989 \\
6 & KPK & $\mathbf{0 , 9 2 1}$ & 0,336 & 0,962 \\
7 & N-total & $\mathbf{0 , 8 9 3}$ & 0,361 & 0,928 \\
8 & P-total & $\mathbf{0 , 9 4 5}$ & 0,295 & 0,980 \\
9 & P-available & $\mathbf{0 , 9 2 6}$ & 0,249 & 0,920 \\
10 & K-total & $\mathbf{0 , 9 6 0}$ & 0,202 & 0,961 \\
11 & K-dd & $\mathbf{0 , 9 5 3}$ & 0,277 & 0,985 \\
12 & Ca-dd & $\mathbf{0 , 9 2 9}$ & 0,308 & 0,958 \\
13 & Mg-dd & $\mathbf{0 , 9 3 7}$ & 0,326 & 0,984 \\
14 & Na-dd & $\mathbf{0 , 8 9 4}$ & 0,283 & 0,880 \\
15 & Total Amount Microbes & 0,697 & 0,701 & 0,977 \\
16 & Respiration Total & 0,141 & $\mathbf{0 , 9 8 1}$ & 0,982 \\
\hline Eigen value & $\mathbf{1 4 , 2 0}$ & 1,05 & \\
\hline
\end{tabular}

Explanation: Bold Numbers Show Common Factor in Each Set of Factors.

The outcome of the factor analysis showed that there are two sets of quality factors (Table 1). Factor I consist of weight volume, soil moisture, permeability, $\mathrm{pH} \mathrm{H}_{2} \mathrm{O}$,
C-organic, KPK, N-total, P-total, P-available, K-total, K-dd, Ca-dd, Mg-dd, Na-dd, total amount of microbes, and total respiration. 
The next screening outcome was also used as a guide in SEM analysis (Picture 2). SEM analysis functions to see the relationship between soil quality factors (physi- cal, chemical, and biological characteristics) where each characteristics was made up of some parameters as well as see the relationship between soil quality factors and the chili outcome.

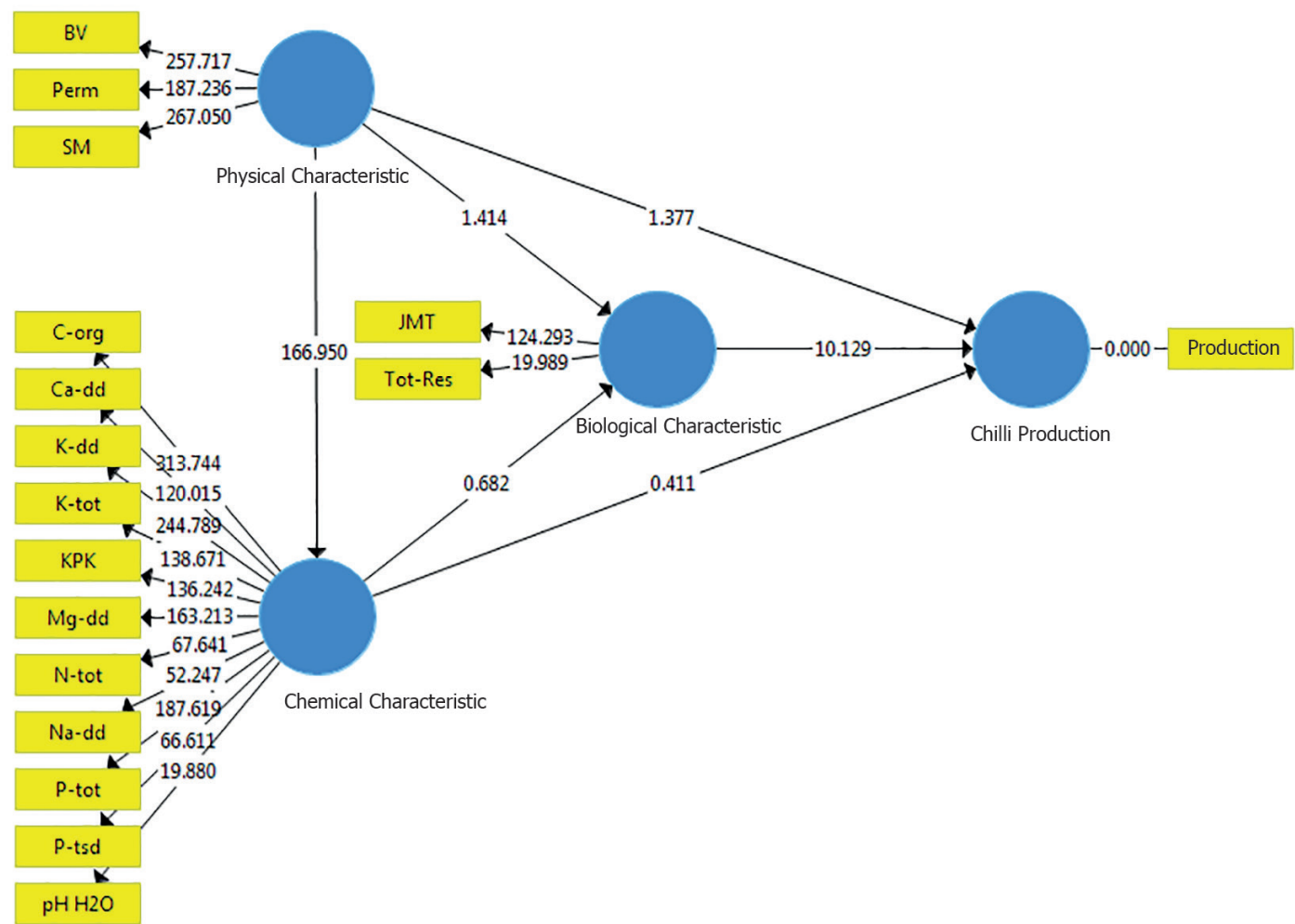

Picture 2. Relationship between Soil Quality Factors and Chili Production

SEM analysis result showed that chili production on a range of argoforestry systems based on coconuts on sandy land of Bugel Beach was affected directly by biological characteristics of soil, while physical and chemical characteristics did not affect chili production directly (Table 2). Other information showed that physical characteristics had a very tight relationship toward chemical characteristics of the soil. The availability of chemical characteristics was affected by the dynamics of physical characteristics of the soil.

Table 2: The Total Effect Between Physical, Chemical, and Biological Characters Toward Chili Production

\begin{tabular}{llllcll}
\hline Total Impact & & Standard Error (STERR) & T Stat & & $\boldsymbol{P}$ Value \\
\hline Physical Character & $\rightarrow$ & Chili Production & 0,276 & 1,377 & $\mathrm{~ns}$ & 0,169 \\
Chemical Character & $\rightarrow$ & Chili Production & 0,269 & 0,411 & $\mathrm{~ns}$ & 0,682 \\
Biological Character & $\rightarrow$ & Chili Production & 0,075 & 10,129 & $* *$ & 0,000 \\
Physical Character & $\rightarrow$ & Biological Character & 1,021 & 1,414 & $\mathrm{~ns}$ & 0,158 \\
Physical Character & $\rightarrow$ & Chemical Character & 0,006 & 166,950 & $* *$ & 0,000 \\
Chemical Character & $\rightarrow$ & Biological Character & 1,034 & 0,682 & $\mathrm{~ns}$ & 0,495 \\
\hline
\end{tabular}

Explanation: There are no significant difference between ${ }^{\mathrm{ns}}$ and ${ }^{*}$, and $\alpha 5 \%$ significant difference. ${ }^{* *}$ significant difference $\alpha 1 \%$. 
The result of SEM analysis potrayed biological characteristics of the soil affecting the production of chili, however there was no information on which biological characteristic that have effect towards it. Gradual regression analysis made the effort to analyze in details on biological characteristic of the soil that take effect in chili production. This analysis pointed out that the amount of microbes in the soil has a significant effect towards the soil production $(\mathrm{P}>0,000)$ (Table 3).

Table 3. Gradual Regression Equation Toward Soil Characteristics That Affect Chili Production.

\begin{tabular}{|c|c|c|c|c|c|}
\hline \multirow{2}{*}{ Parameter Estimation } & \multirow{2}{*}{$\beta$} & \multirow{2}{*}{$\mathbf{t}$} & \multirow{2}{*}{ Significance } & \multicolumn{2}{|c|}{ Collinearity statistics } \\
\hline & & & & Tolerance & VIF \\
\hline Intersep & 28,79 & 7,94 & $0,000^{* *}$ & & \\
\hline Total Amount Microbes & 0,973 & 16,79 & $0,000^{* *}$ & 1,000 & 1,000 \\
\hline
\end{tabular}

$R^{2}=0,946^{* *}$

Explanation: * and ${ }^{* *}$ show significant difference of a $5 \%$ and $1 \%$

Fertile soil consists of a number of microorganisms. P microorganism population in a high level drew the abundace supply of food and sufficient energy, suitable temperature, availability of water and other ecology condition that support the growth of beneficial microorganism in the placement of organism in relation of the rooting system, residual organic matter, and the depth of soil profile.

Microorganism cause biochemistry change (dissolution, fixation, mineralization, immobilization, oxidation, and reduction). The most crucial biochemistry function from microorganism was in the reduction process that takes part consecutively from some nutrients (Yoshida, 1975). As this is so, the chemical characteristic changes that mentioned on the previous statements link to the existence of microorganisms contained in the soil.

The elevation of total amount of microbes in the soil could be done by adding organic matter. The materials that can be used and is affordable for farmers is manure. According to Stevenson (1982), organic matter as a source of nutrients is to provide $\mathrm{N}$, $\mathrm{P}$ and $\mathrm{S}$ for plant growth, biological role influence microflora activities and microfauna organisms, also play physically in improving soil structure, aeration, and moisture storing. Thus, organic matter can accelerate plant growth, ease root dispersion, increase nutrient absorption, multiply chlorophyl syn- thesis and speed up germination (Schnitzer, 1991).

\section{CONCLUSION}

In this study, we identified that Initial agroforestry phase had the highest chili production, followed by middle and then final agroforestry phase. Biological characteristics of soil in general gave a direct leverage toward chili production and significant interaction between physical and chemical characteristics of the soil. Soil quality factor which affect chili production was the amount of soil microbes.

The results of our study provide a better understanding of the relationship between factors of soil quality and the effect of soil quality towards chili production. There are needs to be a follow-through research to elevate physical, chemical, and biological soil fertility in sandy beach area outside of conservation regions.

\section{REFERENCES}

Andrews, S. S., D. L. Karlen and C. A. Cambredella. 2010. The Soil Management Assessment Framework: A Quantitative Soil Quality Evaluation Method. J. Soil Sci. Soc. Am. 68(6): 1945-1962.

Juarini, 2002. Perilaku Petani Terhadap Risiko Usahatani di Lahan Pantai Kabupaten Kulonprogo. Jurnal 
Agroekologi 9:2. Program Studi Ekonomi Pertanian Faperta UGM. Yogyakarta.

Kartonegoro, B. J., 2003. Pengembangan Budidaya Tanaman Sayuran dan Hortikultura Pada Lahan Pasir Pantai: Sebuah Model Spesifik dari Daerah Istimewa Yogyakarta. J. AgrUMY 11(2): 67-75.

Makalew, A. M., 2011. Penetapan Minimum Data Set (Mds) dan Indeks Mutu Tanah Sebagai Landasan Pengelolaan Lahan Berkelanjutan. Disertasi. Program Pascasarjana, Fakultas Pertanian, Universitas Gadjah Mada, Yogyakarta.

Samadi dan Cahyono, 1996. Intensifikasi Budidaya Bawang Merah. Kanisius, Yogyakarta.
Saparso. 2008. Ekofisiologi Tanaman Kubis Bawah Naungan Dan Pemberian Bahan Pembenah Tanah Di Lahan Pasir Pantai. Disertasi. Program Pascasarjana, Fakutas Pertanian, Universitas Gadjah Mada, Yogyakarta.

Schnitzer, M. 1991. Soil Organic Matter. The Next 75 Years. J. Soil Science 151: 4158.

Stevenson, F. J. 1982. Humus Chemistry Genesis, Composition and Reaction. John Willey and Sons, New York.

Yoshida, S. 1981. Fundamental of Rice Crop Science. IRRI, Manila. 